\title{
CORTISONE THERAPY FOR ACUTE UNILATERAL PERCEPTIVE DEAFNESS, AS DEAF MUTE LEVEL
}

\author{
By \\ S. HORIGUCHI AND I. EBIHARA \\ Fram the Department of Oto.Rhno Laryngology, Tokvo \\ Medical and Dental Unvvirsity
}

\begin{abstract}
The authors reported two cases of acute unilateral perceptive deafness who were treated with Cortisone and their hearing returned to almost normal level from $80 \mathrm{db}$ hearing loss. These patients were suffering from slight middle ear infection which was complicated with epipharyngitis anb tubal inflammation, and perceptive derfnesses suddenlv appeared. When the middle ear infect ın was cleared up, perceptive deafness was improved simultaneously. From good results of Cort 1sone therapy the suthors felt that perceptive deafness might be an allergic in nature following slight tubal or middle ear inflammation. Cortisone may be effective for allergic changes or in flammatory hyperstensitiveness of labyrinth due to middle ear infection.
\end{abstract}

\section{興味ある急性感音系難㯖に対する Cortisone 及び Kallikrein 併用療法の治 跧 例}

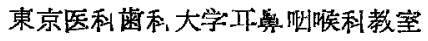 \\ 堀 只申 作・鰕 原
}

\section{I. 粕言}

急性感音系難塄が，片側性に発来する埸合の報告は， 1860 年 Toynbee による 统行性耳下腺炎後の片側性憼 の報告以来，種くの价究報告があり，この程難聴に対す る発病機序についても種くの憶説が報ゼられているか， その治療法に就いて，必ずしも適確に积効すると思われ る療生は現在迄存在しない。

私共は，こ>数年来耳管炎の夏導衈力について，その 内耳病変への影響を検索して来たが，その間耳管炎に誘 発したと思われる片側性急性感音系難聴の 2 例に接し， 僅か Z例てはあるが全例 Cortisone 㱔剂及びカシクレ インの併用滰法により佁撩することを得たので，現下， 急性感音系難聴の治療法の筫困な壮態に扣いて，その治 療生の一睛ともなればと思つて，こっに原著として報告 する・な和本論交の要旨は，日本耳鼻咽喉不字会関東地 方会第 33 回人会に拈いて報告した.

\section{2. 臨床 例}

症例 1. A.K 31 才，古，会社員 (事務職)

初猃。昭和 32 年 12 月 24 日

\section{主訴・右耳急性算性難㯖及び耳鳴}

既往歴；15 16 年前に右側中耳炎の 既往はあるが後 遗症としての難聴は自覚しない。

家族歴；特記すべきるのはない。

現定歴; 昭和 32 年 12 月 17 日朝起 ると突然右耳の 難德之同時に耳鴊を覚えたが，特に耳甬は記憶しなから た・左耳(健耳)を手て战さえると全く右耳に聴力がな く同日都内某医院を尋ねた・発病当時顔面のンビレ感等 はなからた。通気療法正び 鼻咽頭㾞布 $\mathrm{VB}_{1} 100 \mathrm{mg} の$ 在射療层を一週間続けたが，自覚的に 難聴は 全く変ら ず，12月 24 日当外来を訪れた，発病当時自覚的溫冒 䍜患の症头はなかつたが，翼は以前蓄膿症と言われた が，特に鼻漏は多くもなく，鼻の治潦も全く受けていな w.

初診時所見，鼓膜は患耳側に溷斶著明で光錐なく，内 陌は两側共に軽度に存在し，患耳に特に充血はない。前 鼻所見にて右側の孚腫性肥厚を呈した下鼻介を認妨，鼻 咽頭鏡にて特儿右側下鼻介後端に浮腫性限局性の㯌脹を 認める他，咽頭には軽度の充血性病変が見られた。X

$$
5 \div-102
$$




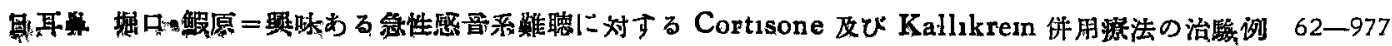

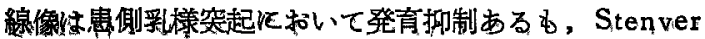

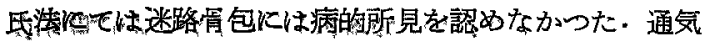
度はやつ不良，患側にて笛声惟音を聴取したが特に出 液を認めない，聴力検查成續は第 1 図の如くてある。

治㙩及び経過: 来院当日より Cort1sone $25 \mathrm{mg} 2$ 月 目より $50 \mathrm{mg}$ の触注を 4 日目迄，同時に，ガタレイ

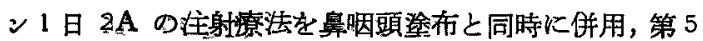
病日上り通院の都合で，コーデルローシン（メルク万有 製） 1 日 $5 \mathrm{mg} 2$ 錠宛内服させた・聴力゙は自覚的に翌 年1月 2 日上り好転し，1月8日にューデルニートンの

第 1 図

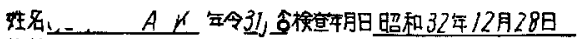

住所

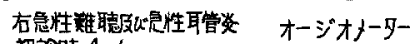

初訪時Audiogra的

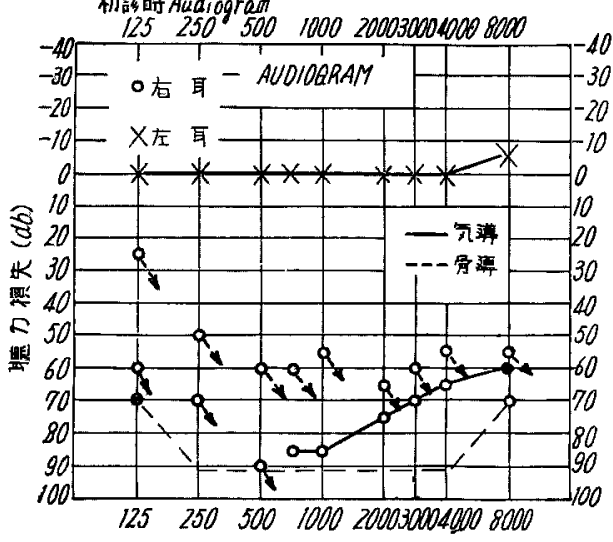

第 2 図

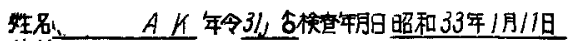

住所

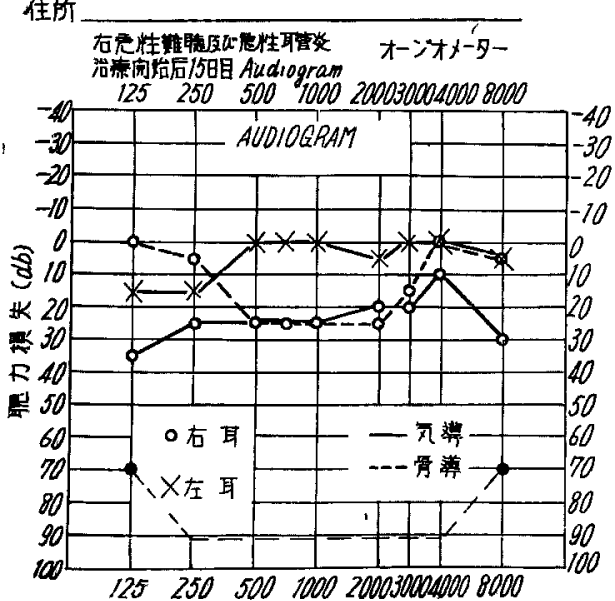

使用を中止し，カリクレイン1日 $1 \mathrm{~A}$ の在射療法を総 量 $20 \mathrm{~A}$ 迄続けた 衈力の改善は第2図の如くである. 1 月11日には枝膜は全く溷獨俏失し，光錐現れ，德力 もかなりに好転したが，耳鳴は殆んぞ 自覚的に改善せ ず，その後 1 月 29 日迄通気度は全く好転するにも拘ら ず，聴力は第 3 函の如く好転せず，1月29日患側下鼻 介後端の浮腫性腫脹部を除去するに及び始めて聴力は第 4 図の如く正常迄好転し，耳鳴の軽減を見た．本症例に 招いては矓最は全経過中全くなく且つ鼓膜所見も全く正 常に復した。

第 3 龱

姓名 住所

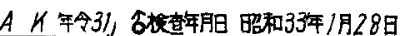

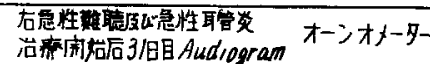

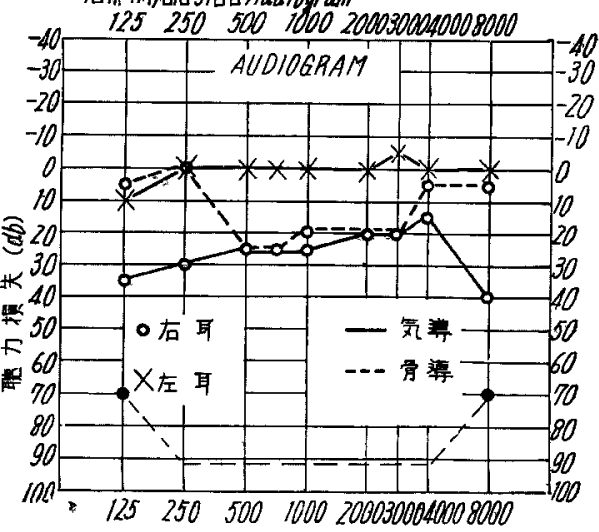

第 4 図

注茄 住所

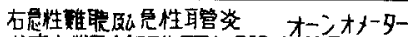

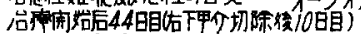

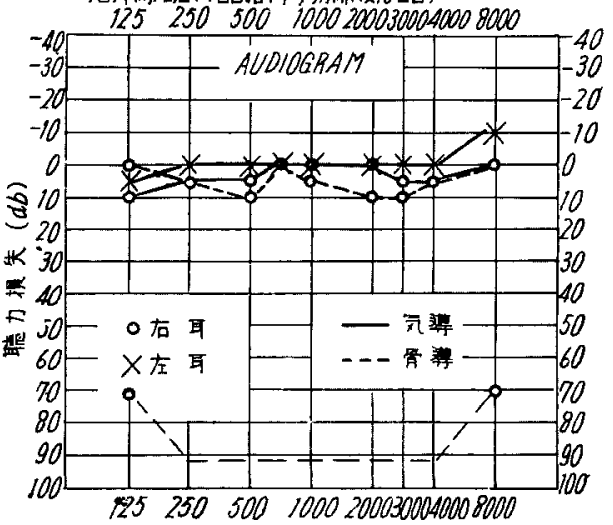


なお本症例に特いてては Cortisone 及びカックレイン 注射の副作用は見られなからた。

症例 2 K.S. 60 才， $\delta$ ，事務職

初診; 昭和 33 年 2 月 3 日

主訴，右耳急性翼性難聴及び耳鸣

既往歴及び家族歴，㭙記すべきるのなし。

現症昰，1月初旬より風邪気味な日が旬日余り続いた が，1月24日夜领酒後就宴，夜間目を醒すと笑然右耳 の耳閉塞感及び難聴に気付き，同時に耳鳴 (ジーン，又 はカーン）る軽度にあった 特に眩最はなく，耳漏もな からた：䍿傽都内某医院を尋水，急性中耳カタ几之言わ れ，鼓膜穿刺㖡を $03 \mathrm{cc}$ 程採取したが，右耳の聴力は全 く好転せず，通気療佉，鼓膜穿刺硣溜液除去，及び $\mathrm{VB}_{1}$ $100 \mathrm{mg}$ の注射療传を連日約 10 日間受けたが聴刀の改善 は見られず，紹介されて 2 月 3 日当外来を訪れた。

初剆時所見 鼓膜所見は，右耳（患耳）飞执いて 強度 に圂㒔し穿刺痕並びに軽度な充血が，棺骨柄及び鼓膜上 辺部に和いて見られ，後鼻镜にて患耳側下鼻介後端の軽 度腫脹，咽頭には漫性の㑡索咽頭炎像が見られた 通気 度は全く湿性㢈音を聴取して㯖く，X線像ては側頭骨"

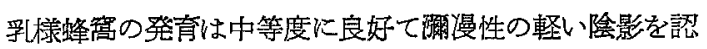
邓たが，Stenver 氏法ては迷路肯包には 異常を認めな

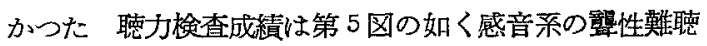
像学呈していた。

治療及び経過，初診当日はプレドニソロン（メルク万 有） $5 \mathrm{mg} 1$ 錠 2 日目よりプレドニソロン $5 \mathrm{mg} 2$ 錠を 2

\section{第 5 図}

姓名 往所

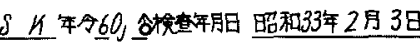

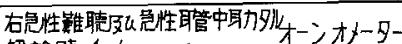
初猃愫A Audiogram

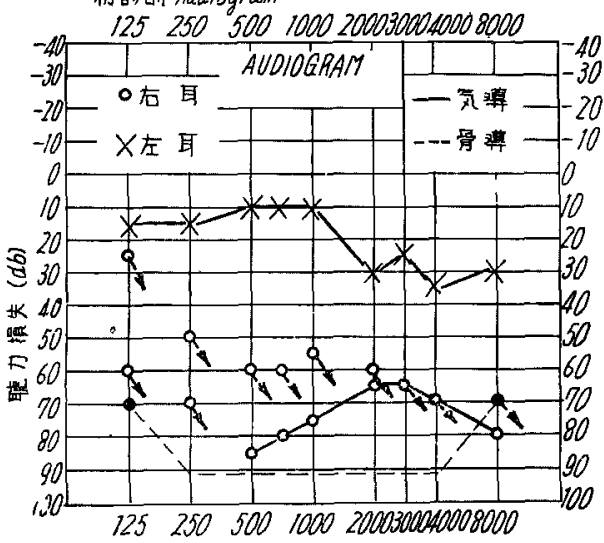

分眼として内服させると同時にカリクレイン1日 $2 \mathrm{~A} の$

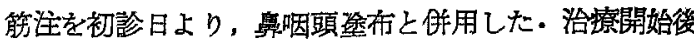
4 日目には第6図に示する如く㶿力は自，他覚的に改善 され，ブレドニソロン（別名ハイトラ）は第 5 日目より は隇量内服し 1 日蛒き1錠とし，カリクレイン(ペイェ

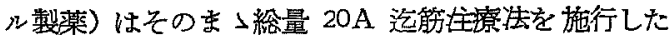
治潦開始後9 日目には第 7 図の如くした，健側耳（左耳） とほら゙同様な位迄㯰力の改善をきたしたので，プレドニ ソロン（メルク万有）の投与を中止した.な虾本例治 潦開始後 22 日目には第 8 凶の如くなり，その後現在迄再

第 6 図

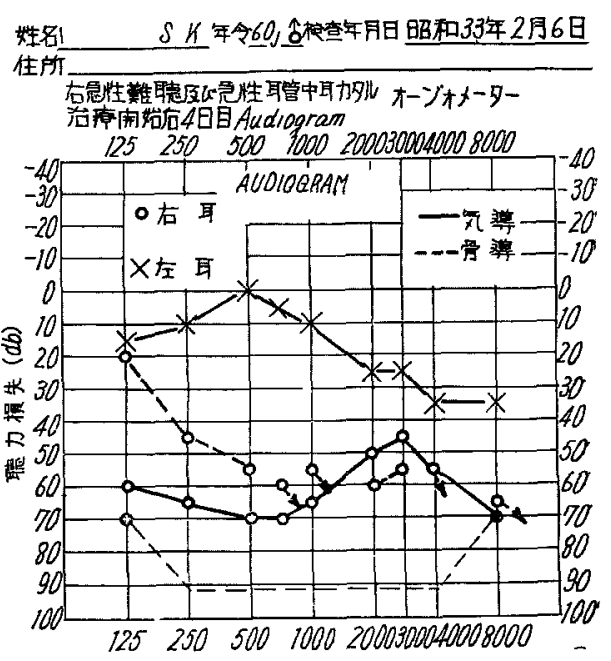

第 7 図

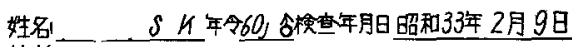
住所

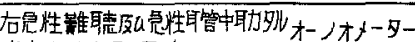

治非宊始后7日目 Audiogram

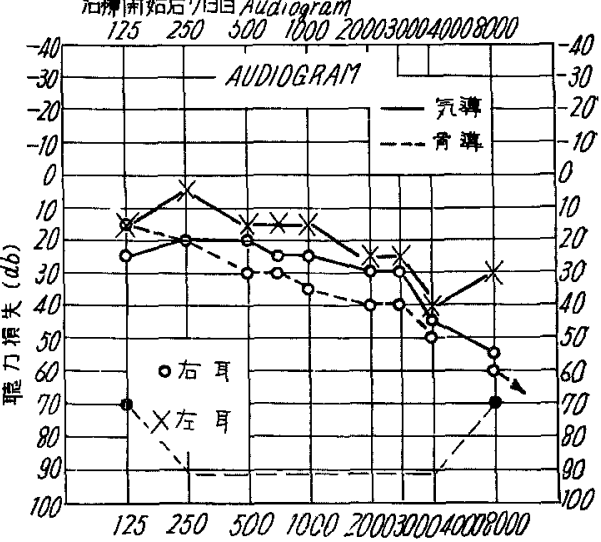




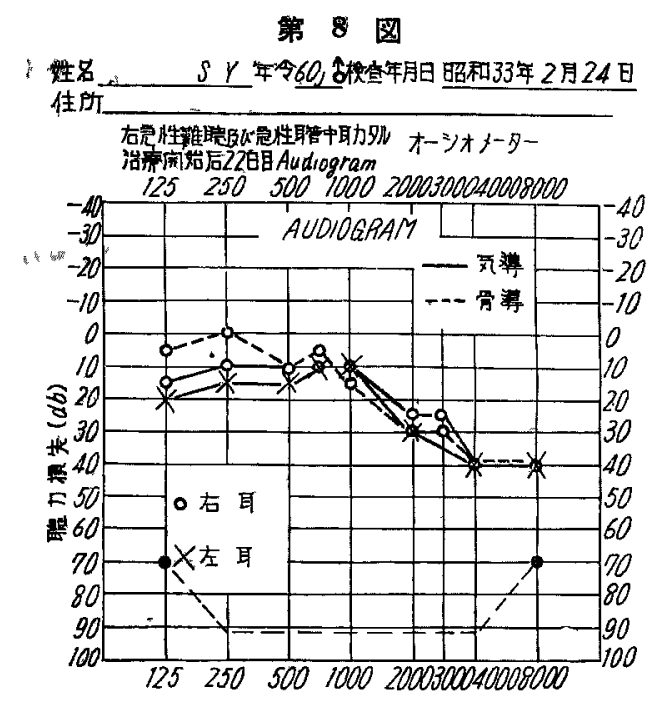

発を見ず，且つ鼓膜所見も全く正常となつた・本例にお いてすCortisone 製郕及びックレイン住射による副 作用は見られなからた。

\section{3. 総括並ひに考按}

以上2例は敦れるその発病形式から見ても明かな上う

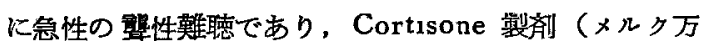
有製）併用により，敦れも殆んぞ正常な聴力に迄恢復し た例である・これ等 2 例は次の如き類似な臨床経過を有 している点興味あるるのである. 即ち，発病後来院迄約 10 日から2週間の間孰れる拕神経炎性ビタミンの注射

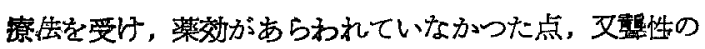
感音采㲟德を有する患耳側中耳及び耳管は第 1,2 例共に 耳管中耳カタルがあり，更に第 2 例では中耳膑内落溜液 を著明に語明するなど，炎症性の所自を有していた点， 次にその発病か笑発性である事且つ耳鳴虫側に有して いるが，䁖最，眩最感共に全経過中観察されなかつたこ と，そしてその耳鳴は聴力が発病前の聴力に恢復しても 耳鳰の好転俚著明でかつた点，父聴力の改善は，本療 注開始後 2 例とも2 週間以内に自他党的改善が見られ， その聴力の好転に先だち中耳及び耳管, 鼻咽頭の急性炎 淀が消遍し，経過を共にしている点非常に興味ある知見 であると思う. 更にその聴政善の点ては，第 2 例ては 有療法開始後 2 3 日以内德力改善の徽候を現し 10 日以内に殆えぞ 健常側迄聴力の 改善している点, その 速效性は注目に価するすの子思われる. 又2症例共に Cørtisone 製剂（メルク方有製）更びカリクレイン（バ
イエル薬品）療击炆し，己むべき副作用を認め得なが つたのは，その速奻性と共に適空を広籍围に拡大する上 で喜ぶべきすのであるらと思う。

從来一般的には急性感音系幙聴には，古くから「ビ口 カルビン療法」が施行好られ，Jakobson を始めとして。 本邦に拈いても二階堂, 鳥居, 水野, 臼井, 吉田, 立 木, 大川们, 佐藤, 義江, 等 1884 年来種々の好結果が 報告されているが，その治潦沙の簡便さの点では本内服 療法に括とるように思われる。耳鳴が後遺症として残る 点では結果的に本療㓐と同結果であるが,こ〉に挙げた 2 症例ては，特に第 1 例て耳耳鳴の著奟な軽減，第 2 例目 では耳鳴の軽減が認められた点特殊例之る考えられなく はないが，カックレイン往射の併用による效果と者考立 られよう・

他に 急性感音柔難聴の 療法としては Fowler (1950), の $0.1 \%$ Novocain の住射潦法，更び㥰辺等 (1955), 堀口 (信) (1953) 等のルチン製剂, $\mathrm{VB}_{1}$ 高単位㱚びカ ワタレイン斉の併用潦法等があるが，本報告例に括ける 程奏效した例に怙いても著明な改善例は余りない，本報 告例に执いては治療開始の時期が全例 2 週間以内て，極 めて早期てあつたためるあららか，来院時迄これらの患 者が $\mathrm{VB}_{1} 100 \mathrm{mg}$ の注射㞠在を受けながら自・他覚的 には殆んぞ潦法の 靑效を認め得なからたことを考え併 せ，本療牲に Cortisone 製剂及びカックレインの併 用漅法があずかつて效果あつたものと考えてよいと思 5 .

又 Mygind (1947) の内耳圧の交倠が 急性難聴の成。

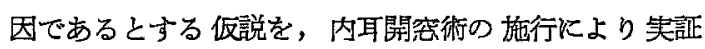
聴力の改善を示した例について, Opheim (1950), Nielsen（1952）等の報告があるか，Nielsen は発病後 11 日目の例ては改善を示さなかつた 1 例を報告，本療 注は極めて初期に施ら行せるべきてあるとしている。

他にる Hallberg \& Horton (1947) による「ヒス タミン」療佉, Williams \& Horton (1950)の「ヒス タミン」及び女性ホルモン剂の併用療法等, 著効ある例. の報告があるが，これらの症例は皆本報告例に括ける如 き，隣接部位の炎症性病变はない例が多く聴力改善の度 合を，恢復の時間的経過に括いて劇的效果を收めた例は 少小。

以上は今迄急性感音采難聴として原因不明とされてき た難聴に対する治療洼の大略てあるが，こ〉に報告した 炎症性所見（特に軽度な）を有する急性感音系難鿵と全 く関㖶のないものとは考觉られないように思克る・何故 
なら, 今迄この種の急性感音系難聴の成因に関する考察 は余りなかつたし，注意して観察された報告は案外少な いからである。

次に本報告例に使用した Cortisone 製剂の耳科領域 における使用を朓めて見ると，内耳開空術前後に乱ける 手術空の肉芽堌生に対する抑制作用及び術後性特液性内 耳炎の消炎潦法，並びに中耳及び耳管に猢りる局所的消 炎潦法を主とし難聴特に感音系難聴の潦法としては，殆 んど見当らない程その報告例は少く，效果なしとする報

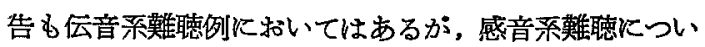
ては試みられてもいない現状である

以上吾々は急性難聴滰法の大方について述へ2 例の Contisone 等による洽験例を挙げたが，これがいかな る mechanism によるものかと言うことに関しては， こっに断言することはできない，その病変が内耳にある か, 後迷路性の arachinit1s として存在しているものか と言らことについても同様である・例充ば後迷路性の arachınit1s Kついては眼科頜域に招ける球後性視神経 炎にその類似性を求めることも可能であるからである. しかし乍ら私共は，この変化を経中耳性江起つた内耳の エレルギー性病変に上るものとの想定のもとに Cortisone 療法を施行したのである.吾々はこ〉数年来耳管炎 による骨導の変化を多数の症例によつて観察しすでに関 東地方会及び 59 回総会に括いて述べた如く,耳管焱に括 いて屡々高音部骨導の著しい低下が見られ，このような 骨導の低下は，全部が全部必ずしも内耳变化によるもの とは考觉にくい，例えば通気後直ち著しい骨導恢復を 見る如き場合はあつても，大行 $25 \mathrm{db}$ を越光ることはな くその多くのものは感音細胞の病变による低下であろう と考えている・而してこのような变化は，少くとる耳管炎 の併存する限り経中耳性にすたらされた病変がアレルギ 一ように進展して内耳に相当著しい变化をるたらしたの ではないかと考えるのてある 即ち耳管炎の場合に拈こ る著明な骨導低下は，一部は中耳性のものであり，一部 は経中耳性淿波及した内耳のアンルギー性変化と考えて いるが，この内耳アレルギー性変化がより高度に出現し て熟を将来したとの考方方に基いて，Cortisone 製風 を使用したわけである・すでに述べた如く Cortisone の発効する機構としては，後迷路性の arachinitis と 今述べた経中耳性波及したアレルギー性内耳炎と言う 二つの process に就する眢の 奏效と言らことを考える ことができるが，しかる，このいずれであるかを决定す ることはできない，但し少くとも，こつに報告した 2 例
に特いては多少とも著明な急性片側性鼻咽腔炎並びに耳 管炎耳管狭窄があり，殊海 2 例飞扣いては明かな急性

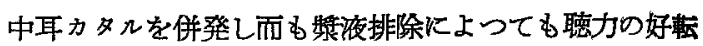
しなかつたことから，上述の如き結論炕達した次第であ る.

な打本療法の適応については今後共症例追加の上検討 の要ありと思っている・

\section{4. 結 論}

急性耳管炎及び急性耳管中耳カタルに合併した算性の 感音系難聴の 2 例を Cortisone 製浏及びカワタレイン 注射の併用療法で殆んど 発病前の 聴力に 迄治瘉唯しめ た. 又成因の一部に経中耳性に進展した内耳のアレルギ 一性病变の存在を想定し,この種の感音絮難聴が炎症性 反応の機転によつて起るものがあると考光た・な虾本療 法の適応については今後症例追加の上検討したいと思つ ている.

\section{参 考 文 献}

1) Jakobson: Arch f. Ohr usw Heilk. 21, 1884.

2) Kosegarten Zeitschr, f. Hals-usw. Heilk, 16, 1886. 3) Barr: Brit. med. jour. July, 1885.

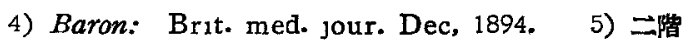

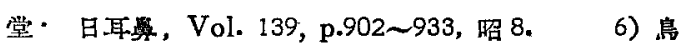

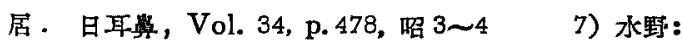

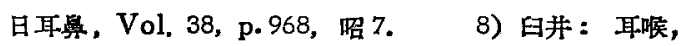
Vol. 21, p. 69 71 1949. 9) 吉田：耳倨, Vol. 21, p.71，1949. 10) 立木：开㑨, Vol. 27, p. 293 297, 1955 11) 立木: 耳喉, Vol. 29, p. 847

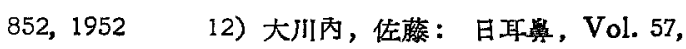
p. 1137，炤 29. 13）義江：日耳量，Vol, 36, p.259 ２76. 14）恢藤：日耳耳尊, Vol. 34, p. 328, 昭 3 4 15) E.P. Fowler: Annal. of O-R-L Vol. 159, p. 980 987，1950.16）波辺・他：耴啹, Vol, 27, p. 222, 1955. 17) 堀口(傍). 日聑鼻, Vol. 56, p. 5๕0, 沿 28. 18) Mygind, S.H. Acta. Otolaryng, Vol. 41, p 278, 1952 . 19) Rasmussen, H.: Acta. Otolaryng, Vol. 137, p. 65, $1949 . \quad 20$ ) Opeim- Acta. Otolaryng, Suppl. 95, p. 58, 1950. 21) Nielsen, J.C.: Acta. Otolaryng, Suppl. 122, 1953. 22) Hallberg, O. and Horton, BT.; "Proceeding of the Staff, Meeding of Mayo Cl1. nic 22, p. 145, 1947 " quoted from Acta. Otolaryng. Vol. 47, p. 270, $1957 . \quad 23)$ Wrlliam, H.L. and Horton, B,T.: Arch. otolaryng, Vol. 51, p.551, 
1950. 24) Lindsay, J.R. \& Zeudema, J.J.: Laryingoskope, Vol. 160, p. 263, 1950 . 25) Kobrak, F.: Handbuch d. Neur. d. Ohres, II Bd. I Teil.

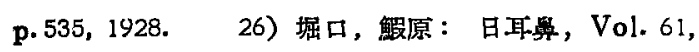
Suppl, p. 18, 1958，27）堀口，鰕原：Audiology, Vol. 1, No. 1, p. 81, 1958.28 2 椐川, 清水: 耳. 臨, Vol. 51. p. 21, 妿 33.29$)$ 涻石, 上西：「示次 モンと䠗床」第 1 卷， p. 103，沿 $28 . \quad 30 ＼mathrm{~ F . D . W . ~}$ Lukens.: "Medical uses of Cortisone" The Blakiston Company, Inc. Toronto. 31) M. Hussarek \& O. Novonty: $\mathrm{Zbl}, \mathrm{H}-\mathrm{N}-\mathrm{O}, \mathrm{He} l \mathrm{k}, \mathrm{Bd} 47$, 1953. 32) H.L. Bell: Eye, Ear, Nose and Throat, Mthl. Vol.31, p.605, $1952 . \quad$ 33) J. Ma. lecki: Zbl, H-N-O, Heilk, Bd56, p. 223, 1956 7. 34) C. Cervellera, \& G. Mazzilli: Z Zbl, $\mathrm{H}-\mathrm{N}-\mathrm{O}$, Heilk, Bd51, p.126, $1954 . \quad 35)$ M. Coassalo: Zbl. H-N-O, Heilk, Bd51, $1953 . \quad$ 39) C.A. Hutchinson: J. Laryng and otol, Vol. 68, p. 189, 1954. 37) J.P. Huber: Zbl. Vol. 51, p. 229, 1954. 38) J.P. Huber: Zbl. H-N-O, Heilk, Vol. 53, p. 69, $1955 . \quad$ 39) J.P. Huber: Zbl. HN-O, Heilk, Vol. 48, p. 152, $1953 . \quad$ 40) B.H. Senturia \& V. Alford: Laryngoskope, Vol. 64, p. $834,1954 . \quad 41)$ R. Grimaud, etc.: Zbl. H-NO, Heilk, Bd59, p.56. 1958.4 42) W. Hartenau:
Mschr, Ohrenheilk, Vol. 88, p.62, 1954.43 ), L. Taeseo, \& R. Manzini: Zbl. H-N-O, Heilk, Bd 57, p. 136, $1957 . \quad$ 44) H.H. Rothendler: Amer. J. med. soc. 275, p. 358, $1953 . \quad 45) K$. Karsten: Arch of otolaryng, Vol. 56, p.427, 1947. 46) M.H. Robbins: Arch. of ophthalm, Voi 48, p. 496, 1952. 47) V. Svanc-Kundsen: Acta Otolaryng, Vol. 147, p. 270, 1957.4 48) E. Boccar \& R. Giordano: Zbl. H-N-O, Heilk, Bd. 56, 1956 7. or Acta, Otolaryng. Vol 47, p. 281, 1957. 49) G.G. Boyd: Arch of otolaryng Vol.65, p. 24, 1957. 50) M.F.Heller, \& P. Lindenberg: Annal of O-R-L, Vol. 64, p.931, 1950 . 51) H.J. Linke: Z. Hals-usw, Heilk, 5, 184, 1955. 52) Everberg. G.: Acta. Otolaryng, Vol. 45, p. 312 321, 1955. 53) T.S. Flynn \& NJ. Woodbury; Arch. otola. ryng, Vol. 65, p 203，1957。 54）浅办，末光：日 耳基, Vol. 53, p. 450, 炤 25.

本報告の終稿に当り，御援助を戴いたメルタ 万有棌式会社並びにーバイエル製薬薬品部の厚意 に深謝するすのでるる。

（原稿到着=㗁和 34.1.19日） 